\title{
FOUNDATION SCIENCE \\ FOR ENGINEERS
}




\section{FOUNDATION SCIENCE FOR ENGINEERS}

Keith L. Watson 
All rights reserved. No reproduction, copy or transmission of this publication may be made without written permission.

No paragraph of this publication may be reproduced, copied or transmitted save with written permission or in accordance with the provisions of the Copyright, Designs and Patents Act 1988, or under the terms of any licence permitting limited copying issued by the Copyright Licensing Agency, 90 Tottenham Court Road, London W1P 9HE.

Any person who does any unauthorised act in relation to this publication may be liable to criminal prosecution and civil claims for damages.

First published 1993 by

THE MACMILLAN PRESS LTD

Houndmills, Basingstoke, Hampshire RG21 2XS

and London

Companies and representatives

throughout the world

ISBN 978-0-333-55477-7

ISBN 978-1-349-12450-3 (eBook)

DOI 10.1007/978-1-349-12450-3

A catalogue record for this book is available from the British Library 


\section{CONTENTS}

Preface

vii

PART 1: FORCE, MATTER AND MOTION

Topic 1: Quantities

Topic 2: Forces and matter 11

Topic 3: Equilibrium 21

Topic 4: Pressure and upthrust $\quad 30$

Topic 5: Displacement, velocity and acceleration $\quad 39$

Topic 6: Force and motion $\quad 50$

Topic 7: Momentum and impulse $\quad 57$

Topic 8: Work, energy and power 63

Topic 9: Motion in a circle 71

Topic 10: Rotation of solids 81

Topic 11: Simple harmonic motion 89

Topic 12: Mechanical waves 99

Topic 13: Electromagnetic waves 111

PART 2: STRUCTURE AND PROPERTIES OF MATTER

Topic 14: Atomic structure and the elements 123

Topic 15: Chemical bonding 134

Topic 16: Heat and temperature 144

Topic 17: Heat transfer 156

Topic 18: Gases 167

Topic 19: Liquids $\quad 177$

Topic 20: Solids $\quad 190$ 


\section{PART 3: ELECTRICITY AND MAGNETISM}

Topic 21: Electric charge

201

Topic 22: Electric field

Topic 23: Capacitance

Topic 24: Electric current

Topic 25: Resistance

232

Topic 26: Some simple circuits

Topic 27: Magnetic fields

Topic 28: Electromagnetic induction

Topic 29: Magnetic behaviour of materials

Topic 30: Alternating current

Answers to Questions

Index 


\section{PREFACE}

This book has been written for students without science A-levels who are entering an engineering degree or Higher National Diploma course via a foundation year. Very little scientific background is assumed and only an elementary knowledge of mathematics, which need extend no further than the simple properties of the right-angled triangle. Calculus is not required.

The book is divided into three parts, which may be taken either in series or in parallel. Emphasis has been placed on clarity and crispness of presentation, and on the provision of appropriate worked examples and practice questions. (The data supplied are approximate and are for illustrative purposes only.)

I have selected those topics which seem to me to provide the essential core material for any engineering foundation course. Practical work is not covered: the inclusion of instructions for safe and effective laboratory exercises over the whole range of topics would have lengthened the book considerably, and, furthermore, the needs of individual courses and the resources of individual institutions tend to determine their particular selection of specific exercises.

I am indebted to many colleagues here at Portsmouth for advice and comments on various parts of the manuscript; in particular, I should like to thank Dr Ray Batt, Professor Trevor Crabb, Michael Devane, Derek Hunter, Dr Tom Nevell, Bob Otter, Ron Parvin and Vic Riches - also Professor Brian Lee for his support. I am especially grateful to Kerry Lawrence of The Macmillan Press for her patience and encouragement, and to Professor John Wilson of the University of Northumbria at Newcastle, who reviewed the manuscript and made many helpful suggestions. Last, but not least, I thank my wife for her powers of endurance.

Portsmouth, 1992

KLW 